\title{
Screening of sorghum genotypes against rice weevil (Sitophilus oryzae L.)
}

\author{
G.R. BHANDERI*, G.G. RADADIYA AND D.R. PATEL \\ Department of Entomology, N.M. College of Agriculture, Navsari Agricultural University, NAVSARI (GUJARAT) \\ INDIA (Email : grbhanderi@yahoo.co.in)
}

\begin{abstract}
Research study on the screening of sorghum genotypes against rice weevil (Sitophilus oryzae L.) on stored sorghum was carried out during the year 2007-08 and 2008-09 at the Main Sorghum Research Station, Navsari Agricultural University, Surat, Gujarat state. Among twelve sorghum genotypes tested, the rice weevil preferred DJ 6514, SR 666, SR 1905 and SR 2460 genotypes for development as compared to other genotypes. On the basis of growth index and susceptible index, the genotypes SR 770, IS 6566, ICSV 700 and 168 II 108 were found less suitable. Among different varieties the sex ratio (male: female) ranged from 1:0.95 to 1:1.31. The genotype DJ 6514 was most susceptible genotype on the basis of damage, weight loss and population build up. The SR 770 maintained maximum germination per cent.
\end{abstract}

Key Words : Sorghum genotypes, Rice weevil, Screening

View Point Article : Bhanderi, G.R., Radadiya, G.G. and Patel, D.R. (2015). Screening of sorghum genotypes against rice weevil (Sitophilus oryzae L.). Internat. J. agric. Sci., 11 (1): 93-98.

Article History : Received : 04.07.2014; Revised : 13.11.2014; Accepted : 30.11 .2014

\footnotetext{
* Author for correspondence
} 